\title{
Åpne refleksjonsgrupper får fram flere diskusjonstemaer
}

Åpent tema får de ansatte på sykehus til å snakke om forhold ved organisasjonen. Det er ikke vanlig i etiske refleksjonsgrupp er.

\section{Forfatter}

\section{Øyvind Taraldset Sørensen}

Hovedprest

Prestetjenesten, St. Olavs hospital

\section{Nøkkelord}

\section{Refleksjonsgruppe Etisk refleksjon Klinisk etikk Organisasjonsetikk Moralsk stress}

Sykepleien 2018 106(65560)(e-65560)

DOI: https://doi.org/10.4220/Sykepleiens.2018.65560

\section{HOVEDBUDSKAP}

På St. Olavs hospital har de åpne refleksjonsgrupper for de ansatte. Denne artikkelen presenterer hvilke temaer de snakker om i refleksjonsgruppene. Relasjonsarbeid framstår som et hovedtema. Personalet er opptatt av hvordan relasjonsarbeidet påvirkes av profesjonalitet og forhold ved organisasjonen. Funnene diskuteres opp mot moralsk stress og etisk refleksjon.

Refleksjonsgrupper for ansatte i helsesektoren har økt de siste årene. I 2016 ble det gjennomført mer enn 200 refleksjonsgrupper på St. Olavs hospital, hovedsakelig for sykepleiere. Siden refleksjonsgruppene har et så stort omfang, kan det være nyttig å få kunnskap om hva de inneholder. 
Pleiepersonalet ved St. Olavs hospital i Trondheim deltar i refleksjonsgrupper, som vi beskriver i denne artikkelen. Refleksjonsgruppene er «uten overskrift», det vil si åpne refleksjonsgrupper der både tema og deltakelse er åpne fra gang til gang. Hensikten med artikkelen er å beskrive hva personalet snakker om i gruppene, og hvordan de snakker om temaene som kommer opp.

\section{三 «I 2016 ble det gjennomført mer enn 200 refleksjonsgrupper på St. Olavs hospital, hovedsakelig for sykepleiere.»}

Refleksjonsgrupper som er beskrevet i litteraturen vi har konsultert, handler ofte om etisk refleksjon (15). Det finnes også eksempler på refleksjonsgrupper om for eksempel likeverdige helsetjenester (6) og åndelig og eksistensiell omsorg i palliasjon (7). Det er særlig i kommunehelsetjenesten etisk refleksjon er beskrevet i Norge (1, 2). Imidlertid har man også i spesialisthelsetjenesten lenge drevet omfattende etisk refleksjon i de kliniske etikkomiteene $(3,5)$.

\section{Åpen refleksjonsgruppe}

Refleksjonsgruppene på St. Olavs hospital gjennomføres som halvtimes grupper. Gruppene som omtales i denne artikkelen, ledes av forfatteren. Gruppelederen baserer seg på elementer fra veiledningsmetodikk som sokratisk dialog og åpne spørsmål (8).

En typisk refleksjonsgruppe kan beskrives slik: Alle ansatte på en sengepost, seksjon eller avdeling, og som ikke er opptatt med arbeid som ikke kan vente, møtes på personalets pauserom til en halvtimes refleksjon om et åpent tema. Deltakerantallet kan variere fra 3-4 og opp til 17-18, med rundt 10 som det vanligste.

Deltakerne er som oftest pleiepersonell. 
Tema for dagen fastsettes etter innspill fra deltakerne, gjerne på bakgrunn av innledningsspørsmålet «Hva skal vi snakke om i dag?». Hvis ingen forslag kommer opp, kan lederen introdusere emner, for eksempel fremme en påstand eller en verdi, eller stille spørsmål som «Hva forbinder du med respekt»?

\section{Metode}

Artikkelen er basert på en analyse av kortfattete notater etter 331 refleksjonsgrupper gjennom 7 år (2009-2016). Gruppelederen skrev ned notater umiddelbart etter hver gruppe. Notatene inneholder for det meste stikkord fra samtalen. Lengden på hvert notat varierer fra et par ord til 6-7 linjer.

Vi analyserte notatene ved hjelp av kvalitativ innholdsanalyse (9). Hovedtemaet består av to deltemaer: profesjonalitet og organisasjonen, som igjen består av flere undertemaer (tabell 1). Analysen viste at relasjonsarbeid var et hovedtema i refleksjonsgruppene.

Tabell 1: Oversikt over temaer i refleksjonsgrupper

\begin{tabular}{|c|c|}
\hline \multicolumn{2}{|c|}{ Relasjonsarbeid } \\
\hline $\begin{array}{l}\text { Profesjonalitet } \\
\text { i relasjonsarbeid }\end{array}$ & $\begin{array}{cc}\text { Deltema } & \text { Organisasjonens } \\
& \text { påvirkning på relasjonsarbeid }\end{array}$ \\
\hline $\begin{array}{l}\text { Undertemaene } \\
\text { (som det snakkes om i gruppene) } \\
\text { - Kompetanse } \\
\text { - Identifikasjon og den andres perspektiv } \\
\text { - Vanskelige følelser } \\
\text { - Egenomsorg } \\
\text { - Verdier og etiske dilemmaer }\end{array}$ & $\begin{array}{l}\text { Undertemaene } \\
\text { (som det som snakkes om i gruppene) } \\
\text { - Arbeidsmiljø og ledelse } \\
\text { - Travelhet } \\
\text { - Intern samhandling og system }\end{array}$ \\
\hline
\end{tabular}

\section{Profesjonalitet}


Her beskriver vi hvordan de fem sidene ved

profesjonalitet som ansatte snakker om i

refleksjonsgruppene, har betydning for relasjonsarbeid.

De fem sidene ved profesjonalitet er kompetanse, identifikasjon og den andres perspektiv, vanskelige følelser, egenomsorg samt verdier og etiske dilemmaer. De er presentert som underpunkter i dette avsnittet. Tekst som står i anførselstegn, er sitater fra notatene.

Kompetanse: «Magefølelse består av klinisk blikk, erfaring, intuisjon.»

Når ansatte snakker om kompetanse, bruker de uttrykk som kvalitet, tillit og magefølelse. Magefølelsen og intuisjonen sørger for det kliniske blikket som prosedyrene ikke kan dekke. Møtet med det som oppleves som fremmed, som språk og kultur, viser at kompetansen ikke alltid strekker til.

Identifikasjon og den andres perspektiv: «Det kunne vært meg.»

Identifikasjon viser seg som møte med seg selv og sine egne erfaringer og de følelsene som oppstår i møte med andre. Det kan se ut som at de ansatte snakker om identifikasjon som en forutsetning for å kunne ta den andres perspektiv.

Det ser ikke ut til å være noe i analysen som tyder på at identifikasjon medfører at personalet forveksler egne behov med andres, noe som ville kunne ha forstyrret relasjonsarbeidet.

Vanskelige følelser: «Jeg skulle ønske jeg kunne ‘skru av hodet og hive det ut gjennom vinduet'.»

Vanskelige følelser kan oppstå både i møte med andre mennesker og i møte med egne erfaringer. Fortvilelse, maktesløshet og hjelpeløshet går igjen når sykepleiere snakker om vanskelige følelser i refleksjonsgruppene. 
Personalet reflekterer også over følelsen av å stå alene fordi de er prisgitt andres vurderinger når en «pasient ... ikke blir smertelindret». De forteller at de ofte kjenner skyldfølelse og føler dårlig samvittighet. De sier at de opplever moralsk stress, for eksempel når alvorlig syke pasienter må flyttes.

\section{三 «Fortvilelse, maktesløshet og hjelpeløshet går igjen når sykepleiere snakker om vanskelige følelser i refleksjonsgruppene.»}

Samtalene i refleksjonsgruppene viser også at døden og døende pasienter kan skape usikkerhet og hjelpeløshet hos personalet. Døden kan oppleves som «elefanten i rommet», den som alle vet er der, men som det likevel er vanskelig å snakke om.

Egenomsorg: «Hvordan sette grenser?»

Ansatte forteller om grensesetting, samvittighet og sinne i refleksjonsgruppene. De snakker om retten til å si nei når grenser overskrides, og de føler seg invadert. Ansatte snakker om egenomsorg, om å anerkjenne egne følelser, og om å snakke med kollegaer om sine vanskelige opplevelser.

Verdier og etiske dilemmaer: « $\AA$ 'føle seg personlig ansvarlig for et mangelfullt system'.»

Analysen viser at personalet benytter gruppene til å reflektere over et mangfold av etiske problemstillinger, som lojalitet, verdighet, likeverd, etisk legitim bruk av makt, anonymitet, ærlighet og ansvar. For eksempel forteller en ansatt hvordan hun ble presset til å ta imot en døende pasient fra en annen avdeling og «blir beskyldt for å nekte» når hun ikke tar imot. Hun opplever det som et spørsmål om verdighet for den døende. 
I en annen gruppe reflekterer personalet over hvorvidt man driver «forskjellsbehandling av ruspasienter [og pasienter med] forgiftninger og selvskading», og hvordan informert samtykke og autonomi utfordres når det i en gitt situasjon refereres til at «legen sa at her er det jeg som bestemmer». De ansatte reflekterer over forholdet mellom omsorg og makt. Spørsmålet om hvilke verdier sykehuset skal ha, og hva vi skal med dem, reises også.

Vi har nå beskrevet hvordan de fem sidene ved profesjonalitet som ansatte snakker om i refleksjonsgruppene, har betydning for relasjonsarbeid. Analysen viser også at personalet er opptatt av organisasjonskultur.

\section{Organisasjonen}

De følgende tre underpunktene er undertemaene som hører til deltemaet «organisasjonens påvirkning på relasjonsarbeid». I refleksjonsgruppene blir organisasjonskultur knyttet til arbeidsmiljø og ledelse, travelhet og intern samhandling og system. I det følgende beskriver vi funnene våre om hvordan disse tre sidene ved organisasjonen påvirker relasjonsarbeidet.

Arbeidsmiljø og ledelse: «Det som holder oss oppe, er et godt arbeidsmiljø.»

Ansatte framhever betydningen av «å være omgitt av mennesker som vil en vel». Et robust arbeidsmiljø har betydning for utholdenhet. På den annen side ser det ut til at utfordringer med fullt sykehus trekker i motsatt retning og bidrar til økt sykefravær. Analysen tyder også på at et arbeidsmiljø som fremmer samhold og trygghet, kan ha betydning for relasjonen til pasienter og pårørende, og for den ansattes relasjon til seg selv. 
Det ser ut som om de ansatte i refleksjonsgruppene særlig er opptatte av relasjonelle forhold ved ledelse, for eksempel kommunikasjon og opplevelsen av ivaretakelse. Ledelse ser ut til å ha betydning for hvordan de ansatte opplever seg selv når de for eksempel snakker om at lederen gir dem lite anerkjennelse.

De snakker også om hvordan ledelse har betydning for hvordan de opplever kollegaene sine når det de kaller «uformelle ledere» får utfolde seg.

Travelhet: «Hvordan få tid til spisepauser?»

Travelhet er et gjennomgangstema i det personalet snakker om i refleksjonsgruppene. Ansatte forteller om hvordan de «må gjøre mer på kortere tid», og at det er «krevende å ikke få tid til samtale og være hos dem som trenger det».

\section{三 «Travelhet er et gjennomgangstema i det personalet snakker om i refleksjonsgruppene.»}

Pasientene blir utrygge når personalet ikke rekker å komme, noe som stresser personalet. Personalet fortviler over at kollegaer «møter gråtende til rapport og går hjem uten å få snakket med noen». Personalet snakker også om andre erfaringer, som for eksempel at det var «bra [med vikarer] i sommer».

Intern samhandling og system: «Respektløshet på systemnivå som rammer individnivå.»

Personalet forteller om systemer som ikke fungerer. Det handler om at leger drøyer, at bakvakten har høy terskel, at pasient døde uten fastvakt, og at behandlere overprøver hverandre slik at «anbefalt smertelindring halveres». Det handler også om kort liggetid, som bidrar til dårlig system for informasjon og for få innleide sommervikarer. 
En annen side ved temaet «intern samhandling og system» er ansattes fortellinger om fullt sykehus. De snakker om hvordan «personalet må 'hive' pasienten ut av rommet fordi ... ny pasient ... [skal] inn nesten før den forrige er klar til å dra hjem». De forteller om hvordan dette fører til at «gamlemor sitter på gangen» med sine poser og vesker, mens rommet hennes klargjøres for en ny pasient.

\section{Oppsummering av funn}

Oppsummert kan vi si at relasjonsarbeidet ser ut til å skje på flere nivåer. Det skjer i selve refleksjonsgruppen, når ansatte sitter sammen og reflekterer. Et annet nivå kan sies å være det som er gjenstand for refleksjonen: relasjonen til pasienter, pårørende, andre kollegaer og hvordan man forholder seg til egne erfaringer og følelser. Et tredje nivå kan være den refleksjonen som foregår inne i hver enkelt i løpet av den tiden refleksjonsgruppen varer: egenrefleksjonen.

\section{Temaer som peker seg ut}

Diskusjonen tar opp hovedområdene for denne artikkelen: å systematisere kunnskap om temaer i refleksjonsgrupper. Hvilke temaer peker seg ut, hva kan grunnen være, og hvordan kan vi forstå de temaene som kommer opp?

\section{Verdier og etikk}

Spørsmål knyttet til verdier og etikk kan oppfattes som et hovedaspekt ved relasjonsarbeid og kan gjenfinnes innenfor de fleste temaene som vi har beskrevet her. Siden verdier og etiske dilemmaer kan sies å være gjennomgående i funnene, kan det tyde på at verdier og etikk er temaer helsepersonell trenger å reflektere over, noe litteraturen om refleksjonsgrupper bekrefter (1-4).

\section{Moralsk stress}


Moralsk stress kan oppstå når vi vet hva vi synes det er riktig å gjøre, men forhindres av ytre rammer (10).

Moralsk stress i helsesektoren er godt dokumentert (1, $4,10)$. I materialet vårt har vi sett hvordan moralsk stress påvirkes av for eksempel organisatoriske forhold som travelhet og intern samhandling og system, og har innflytelse på de relasjonelle møtene.

Et eksempel på moralsk stress er den tidligere nevnte sykepleieren som føler seg presset til å ta imot en døende pasient. Sykepleierens verdier og moralske integritet tilsier at en døende pasient ikke skal flyttes fra en avdeling til en annen. Likevel føler hun seg presset av et system der forholdet mellom kapasitet og pågang ikke synes å være i samsvar, med den følge at en døende pasient forsøkes flyttet.

Pasienten ble ikke flyttet fordi sykepleieren opplevde flyttingen som en krenkelse av pasientens verdighet og sto på sitt, selv om hun ble beskyldt for å nekte. Hun sto i det moralske stresset og handlet i samsvar med sine profesjonelle og personlige verdier. Selv om det var krevende, er det grunn til å framheve betydningen av å handle autentisk, i samsvar med sine moralske følelser (11).

Studier viser at denne formen for autentisitet kan bidra til jobbengasjement og trivsel (12). Motsatt viser studier at sykepleiere som ofte blir utsatt for moralsk stress, står i fare for å bli emosjonelt utmattet og innta et avpersonalisert forhold til pasienter, med fare for å bli utbrent (10). Plassmangel og press på avdelinger om å ta imot nye pasienter kan bidra til at moralsk stress oppstår.

\section{«Det å få snakket sammen kan kanskje gi overskudd til å ta problemene videre.»}


Slikt stress oppstår når avstanden blir for stor mellom egne verdier og moralsk integritet på den ene siden, og forventningene fra organisasjonen og dens evne til å løse interne samhandlingsutfordringer på den andre siden. Resultatet kan bli at individet, den enkelte profesjonsutøveren, forsøker å ta ansvar for utfordringer som organisasjonen er ansvarlig for.

Refleksjonsgruppene gir personalet mulighet til å snakke sammen om mangelfulle organisatoriske systemer. På den måten kan gruppene fungere som ventiler der ansatte får lettet på frustrasjonstrykket, noe som kanskje kan bidra til å opprettholde det mangelfulle systemet. På den andre siden kan det å få snakket sammen kanskje gi overskudd til å ta problemene videre.

\section{Refleksjonsgruppens form}

Funnene indikerer at personalet i refleksjonsgruppene har behov for å snakke sammen om utfordringer som oppstår som følge av utilstrekkelige organisatoriske forhold. De viser også at refleksjonsgruppens åpne form kan bidra til å legge til rette for slik samtale.

Temaene som kommer opp i etisk refleksjon i spesialisthelsetjenesten, slik det kommer til uttrykk i kliniske etikkomiteer, handler som oftest ikke om organisatoriske forhold (5).

Hva kan da grunnen være til at utilstrekkelige organisatoriske forhold kommer opp i våre grupper? Det er ikke sannsynlig at det skyldes lokale forhold. Kanskje kan refleksjonsgruppens åpne form ha betydning. Kan det være slik at organisatoriske forhold blir for komplekst for etisk refleksjon (13)? At utfordringer og dilemmaer som mer direkte utfordrer den enkeltes profesjonelle ferdigheter, egner seg bedre for etisk refleksjon? 
Et eksempel kan være problemstillinger knyttet til fortsettelse eller begrensing av livsforlengende behandling (5). Det kan også være andre utfordringer som har med medbestemmelse å gjøre (5). Den medisinske etikken fokuserer på prinsipper som autonomi, det å gjøre vel imot andre og ikke skade (14).

Vi spør oss om det kan være slik at denne oppmerksomheten heller inviterer til å håndtere etiske dilemmaer som handler om individuelle perspektiver, enn organisatoriske forhold? Dersom individet, den enkelte ansatte, føler at man må ta ansvar for det organisasjonen er ansvarlig for, kan det innebære at organisasjonen ikke blir ansvarliggjort.

\section{Gruppens betydning}

Hvilken betydning har refleksjonsgruppene for de ansatte? I framtiden vil det være viktig å dokumentere denne betydningen, tatt i betraktning det omfanget refleksjonsgruppene har. Gruppenes betydning faller utenfor rammen for denne artikkelen.

Refleksjonsnotatene gir likevel noen antydninger:

Ansatte omtaler gruppene som det «eneste stedet man kan ta opp hva som helst». De snakker om gruppene som et sted for ettertanke og nye perspektiver, et «pustehull». Noen forteller også at de «tenker på det vi har snakket om når liknende situasjoner dukker opp».

Takk til professor Kjersti Vik, Institutt for nevromedisin og bevegelsesvitenskap, NTNU for veiledning i metode og konstruktive innspill da vi skrev artikkelen.

1. Vråle GB, Borge L, Nedberg K. Etisk refleksjon og bevisstgjøring i veiledning. Sykepleien Forskning 2017. Tilgjengelig fra: https://sykepleien.no/forskning/2017/04/etiskrefleksjon-i-veiledning (nedlastet 25.04.2017). 
2. Magelssen M, Gjerberg E, Pedersen R, Førde $\mathrm{R}$, Lillemoen $\mathrm{L}$. The Norwegian national project for ethics support i community health and care services. BMC Medical Ethics. 2016;17:70-8.

3. Magelssen M, Pedersen R, Førde R. Novel paths to relevance: How clinical ethics committees promote ethical reflection. HEC Forum 2016;28(3):205-16.

4. $\quad$ Engerdahl IS, Molewijk A, Pedersen R. Etiske utfordringer ved bruk av tvang i psykisk helsevern - Når lovverk møter praksis. Tidsskrift for Norsk psykologforening. 2016;53(2):102-10. Tilgjengelig fra: http://www.psykologtidsskriftet.no/index.php? seks_id=457512\&a=3\#article (nedlastet 10.03.2016).

5. $\quad$ Førde R, Pedersen R. Clinical ethics committees in Norway: What do they do, and does it make a difference? Cambridge Quarterly of Healthcare Ethics. 2011;20:389-95.

6. Kartzow AH, Flateby IV, Debesay J.

Refleksjonshåndbok for helsepersonell. Om mestring av flerkulturelle utfordringer. Oslo: Oslo universitetssykehus, Seksjon for likeverdig helsetjeneste; uten årstall.

7. Lunde SAE, Haugen DF, Austrheim MH. Palliasjon er også eksistensiell omsorg. Sykepleien Forskning 2017. Tilgjengelig fra: https://sykepleien.no/forskning/2017/08/palliasjon-erogsa-eksistensiell-omsorg (nedlastet 27.09.2017).

8. $\quad$ Skagen K. I veiledningens landskap. Innføring i veiledning og rådgivning. 2. utg. Oslo: Cappelen Damm; 2013.

9. Lundman B, Graneheim UH. Kvalitativ innehållsanalys. I: Granskär M, Höglund-Nielsen B, red. Tillämpad kvalitativ forskning inom hälso- och sjukvård. 2. utg. Lund: Studentlitteratur; 2012. 
10. Oh Y, Gastmans C. Moral distress

experienced by nurses: a quantitative literature review.

Nursing Ethics. 2015;22(1);15-31.

11. Taylor C. Autentisitetens etikk. Oslo:

Cappelen Akademisk Forlag; 2004.

12. Bjarnadottir A, Vik K. Experiences of staying healthy in relationally demanding jobs: an interpretative phenomenological study of workengaged nurses in the hospital. Open Journal of Nursing. 2015;5:437-50. DOI:

10.4236/ojn.2015.55047.

13. Førde R, Hansen TWR. Do organizational and clinical ethics in a hospital setting need different venues? HEC Forum. 2014;26:147-58.

14. Beauchamp TL, Childress JF. Principles of Biomedical Ethics. 6. utg. New York: Oxford University Press; 2009. 